\title{
トラマドール／アセトアミノフェン配合錠の 少量投与についての検討
}

\section{小畑ダニエル* 藤井洋泉* 香曾我部義則* 梶木秀樹*}

[要旨］トラマドール塩酸塩／アセトアミノフェン配合錠 (Tramadol Hydrochloride/Acetaminophen tablets : T/A 錠)は一般的な投与量では副作用による投与中止率が高いことが報告されて いる. そこで当院における非がん性慢性疼痛に対する $T / A$ 錠の投与量と副作用の発現率, 投与中 止率について検討した. $\mathrm{T} / \mathrm{A}$ 錠平均開始量 $1.3 \pm 0.7$ 錠/日, 平均維持量2.1 $1 \pm 1.2$ 錠/日の少量 投与で, 副作用発現率 $9.3 \%$, 投与中止率 5.6\%で，これまでの報告と比較し少ない傾向がみられ た.

キーワード : トラマドール塩酸塩/アセトアミノフェン配合錠, 初回投与量, 副作用

\section{はじめに}

トラマドール塩酸塩／アセトアミノフェン配合錠 (Tramadol Hydrochloride/Acetaminophen tablets：T/A 錠)は2011年に本邦でも非オピオイド鎮 痛薬で治療困難な非がん性慢性疼痛に対し使用可能 となった。しかし，国内での臨床試験において，4 錠/日の投与量では高率に副作用が出現することが 確認されている ${ }^{1) 2}$. 一方, 少量から開始し, 徐々 に増量 (漸増投与法)することで, 副作用による中止 率が有意に低下することが知られている ${ }^{3) \sim 5)}$. われ われはこれらの報告の後ろ向きの追試として，T/ $\mathrm{A}$ 錠の副作用発現率および中止率について検討し た。

\section{I 方 法}

本研究は後ろ向き観察研究で，2011年8月から *医療法人社団三樹会梶木病院麻酔科
2013年4月の間に，非オピオイド鎮痛薬でも痛みの 軽減が得られず $\mathrm{T} / \mathrm{A}$ 錠を処方開始された患者を対象 にし，2013年6月までを観察期間とした。投与法お よび投与量は担当医師の判断に任された。患者の承 諾および梶木病院倫理委員会の承認を得た後, $\mathrm{T} / \mathrm{A}$ 錠の初回投与量，維持投与量，副作用の種類および 発現率，投与中止の有無について診療録からデータ を集積し検討した。データは平均值士標準偏差で表 した.

\section{II 結 果}

対象患者は266名(男性 115名，女性 151名)，年 齢は $68 \pm 13$ 歳であった。疾患は腰部脊柱管狭窄症： 59 例, 変形性脊椎症 : 48例, 腰椎椎間板ヘルニア : 33 例，春椎手術後痛症候群 : 32 例，肩関節周囲炎 : 22 例, 変形性膝関節症 : 21 例, 頸椎症 : 14 例, 頸 椎椎間板ヘルニア : 7 例, 帯状疮疹後神経痛 : 7 例, 
腰椎すべり症 : 6 例, 腰椎椎間板症 : 5 例, その他 : 12 例であった。

$\mathrm{T} / \mathrm{A}$ 錠の平均開始量は $1.3 \pm 0.7$ 錠/日，維持量は 平均 $2.1 \pm 1.2$ 錠/日だった。

検討期間中に 25 例 $(9.3 \%)$ に副作用がみられた。 嘔気・嘔吐が7例 $(2.6 \%)$ ，ふらつきが 4 例 $(1.5 \%)$, 眠気が 4 例 $(1.5 \%) ，$ めいが 2 例 $(0.8 \%) ，$ 便秘が 2 例 $(0.8 \%)$ ，その他が 6 例 $(2.2 \%)$ だった。そのうち 7 例 $(2.6 \%)$ は初回投与量で副作用が発現した(嘔気・ 嘔吐 : 3 例, めまい: 2 例, 眠気 $: 1$ 例, 悪寒 $: 1$ 例).

検討期間中に 15 例 (5.6\%) が副作用により中止と なった〔嘔気・嘔吐: 7 例 $(2.6 \%)$ ，ふらつき:2例 (0.8 $\%)$, めまい: 2 例 $(0.8 \%)$, その他: 4例]. 11例(4.1 \%)で痛みの軽減がみられず中止となった。

\section{III 考 察}

非がん性慢性疼痛患者に対し $\mathrm{T} / \mathrm{A}$ 錠を投与され た症例で，投与量，副作用発現率，投与中止率につ いて後ろ向きに検討した。一般的に推奨されている 投与量より少量で，投与開始時および維持時の副作 用発現率が低く，中止率もこれまでの報告と比べ低 かった.

$\mathrm{T} / \mathrm{A}$ 錠の非がん性慢性疼痛および抜歯後に対す る国内臨床試験では，1回1錠，1日4回投与で嘔気, 嘔吐，傾眠，便秘，めまいなどの副作用が $81.1 \% の$ 症例にみられた ${ }^{1)}$. 副作用は治療開始 1 週間以内に 高頻度に発現したが，それ以降の発現は減少した。

投与量と副作用の発現率に関しては, 用量依存性 がみられ，漸増して投与することにより，副作用に よる中止率が有意に低下したと報告されてい

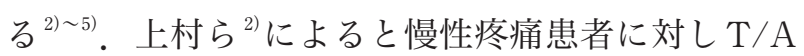
錠を 1 日 1 錠から内服を開始し，1週の間隔で 1 錠 ずつ増量(平均投与量 1.91 錠) した結果，副作用発現 率は $19.4 \%$ (悪心 $3.6 \%$, 嘔吐 $1.0 \%$, 便秘 $10.7 \%$ ，傾 眠 $2.6 \%$ ，めまい $0.5 \%)$, 副作用による内服中止率 が10.7\%だった。また投与量を漸増する期間が長い 方が，中止率が低いことも報告されている，Ruoff ${ }^{3)}$
の報告では，10日間かけてトラマドール投与量を 200mg まで増やした群の方が1日，4日間漸増群と 比べて副作用による中止率が有意に低かった(10日 間漸増群 $15.2 \%$ ，4 日間漸増群 $24.0 \%$ ，1 日漸増群 $30.8 \%)$. Petrone ら ${ }^{4)}$ も，10日間と 16 日間でトラマ ドールを $200 \mathrm{mg}$ まで漸増した群の比較では 16 日間 漸増群の方が中止率が有意に低かった(16日間群 33.9\%，10日間群53.7\%) と報告している。Choi ら ${ }^{5)}$ による報告でも同様に副作用発現率は漸増した群で 有意に低く，副作用による中止率 $(10.5 \%)$ も低かっ た。本研究は後ろ向き研究であり, 決まった投与法 や漸増時間はなかったが，われわれの平均維持量は $2.1 \pm 1.2$ 錠(トラマドール量として $78.75 \pm 45 \mathrm{mg}$ ) で 上村らの報告 (平均 1.91 錠 =トラマドール $71.6 \mathrm{mg}$ ) と ほぼ同量であったため，副作用の出現率はほぼ同率 だったと考える. Ruoff, Petrone ら, Choi らのトラマ ドール維持量(それぞれ 200mg，200mg，112.5mg) と比較すると本研究での維持量は少量であり, 漸増 して投与されたにもかかわらずわれわれの結果と比 べ中止率が高かったものと思われる。

\section{まとめ}

平均開始量 1.3 錠/日，平均維持量 2.1 錠/日の $\mathrm{T} /$ $\mathrm{A}$ 錠投与で，副作用の発現率および中止率がこれま での報告と比べ低い傾向がみられた。しかし，本研 究は後ろ向き研究であり, 非がん性慢性疼痛に対す る $\mathrm{T} / \mathrm{A}$ 錠の安全な投与量(開始量, 維持量)の確定 には前向き研究が必要である。

本論文の要旨は日本臨床麻酔学会第 33 回大会 (2013，金沢)にて発表した。

\section{参考文献}

1）新谷悟, 小村健, 久保田英朗ほか：抜歯後疼痛に対す るJNS013(トラマドール塩酸塩/アセトアミノフェン 配合錠)の臨床評価：各配合成分の単独投与の二重盲検 比較試験. 日口外誌 $58: 110-122,2012$

2）上村幹男, 内山茂晴, 加藤博之：慢性疼痛に対する新 
しい鎮痛薬トラムセット配合錠：漸増投与法による副 作用対策一 209 例の使用経験からの分析一. Prog Med 32 : 1671-1676, 2012

3) Ruoff GE : Slowing the initial titration rate of tramadol improves tolerability. Pharmacotherapy $19: 88-93$, 1999

4) Petrone D, Kamin M, Olson W : Slowing the titration rate of tramadol $\mathrm{HCl}$ reduces the incidence of discontinuation due to nausea and/or vomiting: A double- blind randomized trial. J Clin Pharm Ther 24 : 115123, 1999

5) Choi CB, Song JS, Kang YM, et al. : A 2-week, multicenter, randomized, double-blind, double-dummy, add-on study of the effects of titration on tolerability of tramadol/acetaminophen combination tablet in Korean adults with knee osteoarthritis pain. Clin Ther 29 : 1381-1389, 2007

\title{
The Use of Low Initial Doses in Tramadol/Acetaminophen Combination Treatment
}

\author{
Daniel OBATA, Hiromi FUJII, Yoshinori KOSOGABE, Hideki KAJIKI \\ Department of Anesthesiology, Kajiki Hospital
}

Studies have shown that tramadol hydrochloride/acetaminophen(T/A) tablets are associated with a high incidence of adverse events leading to discontinuation when administered at the generally prescribed dose of 4 tablets/day. We aimed to assess the incidence of adverse events and discontinuation in patients who received T/A tablets for chronic non-cancer pain. Reducing the initial dose of T/A tablets may lead to a decreased incidence of adverse events and discontinuation.

Key Words : Tramadol Hydrochloride/Acetaminophen tablets, Initial dose, Adverse events

The Journal of Japan Society for Clinical Anesthesia Vol.34 No.7, 2014 